\title{
THESAURUS APPROACH: ON THE FORMATION OF MATHEMATICAL COMPETENCE AND COMPETENCE OF FUTURE ENGINEERS
}

\section{Riskeldi Musamatovich Turgunbaev}

Candidate Of Physical And Mathematical Sciences, Associate Professor, Department Of "Algebra, Geometry, Mathematical Analysis", Tashkent State Pedagogical University, Uzbekistan

Umurbek Ibadillaevich Kushmurotov

Senior Teacher, Department Of “Higher Mathematics And Information Technology”, Navoi State Mining Institute, Uzbekistan

\section{ABSTRACT}

In the article, the question of improving the formation of mathematical competencies and competencies of future engineers on the basis of a fast-paced approach is developed, in particular, the main concepts, the main issues of the topic, the importance of building a thesaurus, which includes the methods of activity for solving these issues.

KEYWORDS:- Higher Mathematics, Competency approach, mathematical competence, competency, methods of activity, methods of mathematical activity, thesaurus approach, cycle of issues.

\section{INTRODUCTION}

Changes in socio-political and economic conditions have determined the requirements for the quality and level of preparation of graduates of higher educational institutions. An increase in the demand for a socially active person, who can make independent decisions and feel responsibility for the implementation of decisions, leads to the modernization and improvement of the functions of the higher education system.

5314400-Mineral Enrichment, 5111000Vocational Education (5311600-Mining), 5311600-Mining (Open Mining, Underground Mining), regardless of the basic calculation of science or qualification, is the total for all specialties of the received professional knowledge and in all volumes of the time of training. The analysis of the content and structure of the course of mathematics for the technical higher educational institution system, sample curricula, textbooks on mathematics and teaching aids has shown that the available methodological provision, the rich experience and traditions accumulated in teaching mathematics in technical higher educational institutions, often do not adapt to specific specialties and do not always fully ensure that education is In addition, the methodology of training, which serves to carry out a full-fledged competence approach, which is one of the bases of the reforms carried out in the field of education in the Republic, has not been developed. The foregoing shows the relevance of the study of future engineers on the description of mathematical competence and the 
methodology for its formation.

\section{THE MAIN FINDINGS AND RESULTS}

In scientific research devoted to the mathematical competencies and competencies of future specialists, it describes mathematical comets in general for the course of holistic mathematics. For Example, V.A. Shershneva [1] says the following about the mathematical competence of future engineers. Mathematical competency is an integrative dynamic property of a student's personality, which he says characterizes the ability and willingness of the student to use mathematical modeling techniques in his / her professional activities. Mathematical competency combines the mathematical knowledge, skills and skills provided for by educational standards, as well as the general cultural and professional competences that are projected into the subject area of mathematics - their main core is the ability and readiness of the graduate to apply this knowledge in his professional activity.

The clarification of this definition for a particular subject of higher mathematics causes much more complexities. For this reason, the need arises for the development of working methods of determining the mathematical competences of the future specialist. To this end, we will improve the mathematical concepts of competence and competency, developed for AJ.Jafyarov's school mathematics, for higher mathematics.

A.J.Jafyarov [2; 3] talked about the different interpretation of the concepts of competence, competence in the scientific literature; he gives his own definitions to these concepts. According to these definitions, compensation is the name of an activity in a certain sphere of human activity; its essence is that mankind should be ready to solve certain problems in this sphere of activity. And competence represents the degree to which a person occupies these competent. It follows from this that the competence belongs to the whole of mankind, and the competence belongs to the individual.

The author proposes to introduce a competency approach into the training process in three stages:

The first stage is the formation of the basic competences of the object of study (subject, educational science, combined didactic unit); the second stage is the formation of the basic competences on the whole object of study; the third stage is the development of the holistic improvement of the competences on the main object of study.

The general requirements for the formation of competency are as follows [3]:

a) To know the definitions and properties of the basic concepts that constitute the basis of this basic competence;

b) To have the ability to apply this knowledge in solving educational and practice-oriented issues;

c) To have the knowledge and skills to solve standard and non-standard issues, to put in place problems and to solve them;

d) To have skills in innovation, creative and research activities;

e) To constantly improve their knowledge and skills, knowledge of the materials under study and research activities in the process of studying the subsequent subjects of this and other disciplines.

The second stage is the formation of the basic competency, that is, the competence over all the basic competences of the object of study, which includes the following steps.

The first step is to "teach ideas". The joint activities of the teacher and students are aimed at the creative and critical assimilation of the 
CURRENT RESEARCH JOURNAL OF PEDAGOGICS 2(7): 26-33, July 2021

DOI: https://doi.org/10.37547/pedagogics-crjp-02-07-07

ISSN 2767-3278

(C)2021 Master Journals

\section{Crossref dof 81 Google}

Accepted 26thuly, 2021 \& Published 31 th July, 2021

theories and methods of its application, which are now captured by mankind.

The next process occurs as a result of explaining the theory, presenting clarifying examples, analyzing the examples presented; they represent a broad class of typical issues given together with their solutions.

The second step is to "teach thinking". It is carried out through independent solutions and Specially Selected Topics for creative assignments. Using this material, we formulate the responsibility, independence of students and, most importantly, the skills of research and creative activity.

The third stage is the improvement of the student's competence in the object of study by using knowledge, skills and skills in the process of studying the subsequent subjects of this science (improving the competence on the vertical) and specialized (related) subjects (improving the competence on the horizontal).

In the introduction of the competency approach proposed by A.J.Jafyarov [3] into the educational process, it is important to note that the following are: a) updated theory and methods of its application to the solution of issues and problems (here students are actively involved in the development of these techniques, as a result of which they acquire the skills of critical thinking and innovation The author says that the inclusion of the proposed technology in the educational process serves to improve the quality of mathematics education, has a simple method of implementation, which contributes to the introduction of a compensatory approach to the educational process. This method consists of two parts. This method consists of two parts. In the first part, didactic support of the subject (subject, subject of study, etc.) is created, in the second - the activity of students is activated in accordance with the requirements for the formation of the required basic competencies.
In our opinion, it is worthwhile to enrich the author's proposals for the introduction of a competency approach into the educational process with a thesaurus approach [4;5] in the application of mathematics in higher education institutions. Here, the thesaurus approach allows clarifying the didactic provision of the subject or module of Educational Science, in particular the content of Education. In addition to the basic concepts of educational science, it is desirable to include methods of educational activity (methods of universal activity, methods of general mathematical activity, methods of activity specific to individual sections of Mathematics, Methods of private activity for solving basic issues), a system of basic issues on each topic and methods of activity for solving these issues.

In this case, the composition of the competencies on each subject of Higher Mathematics can be formulated as follows:

a) To know the basic concepts and principles of the subject;

b) To know the properties of the basic concepts of the subject and the laws that characterize the relationship between the previously studied concepts;

c) To know and apply the methods of action to solve the main issues related to the subject matter;

d) To tour, move the methods of activity to solve the main issues related to the topic in order to solve new issues;

e) To apply the above-mentioned competences in the study of related and professional Sciences.

For example, the thesaurus on the topic "Second and third order determinants. Methods for calculating the determinant. Basic properties of the determinant. Minors and algebraic complements, the concept of n-order determinants" can be formed as follows: 
Basic concepts: second order determinant, definition, diagonal Elements, line elements of the determinant, column elements, calculation of the determinant, properties, 3-order determinant, order of the determinant, minor, algebraic complement, triangle method of calculation of the 3-order determinant, sarrius method, spread method on line or column elements, calculation of the $\mathrm{n}$ - order determinant, Zero Transformation of column or row elements, spread method on line or column elements, you know what?

Main features:

1. If two line (column) elements of the determinant are the same, then the value of this determinant is zero.

2. If two line (column) elements of the determinant are proportional, then the value of this determinant is zero.

3. If the line (column) elements of the determinant are zero, then the value of this determinant is zero.

4. If the corresponding row (column) elements of the determinant are replaced, then the value of the determinant will not change.

5. If two line (column) elements of the determinant are exchanged in place, then the sign of this determinant changes to the opposite of the dependent.

6. The size of a determinant is equal to the number of elements of a row (column) added to it by multiplying it by the corresponding algebraic fillers.

7. If the Determinant consists of two Joins of each element of one row (column), then this determinant will be equal to the sum of two determinants, that is,

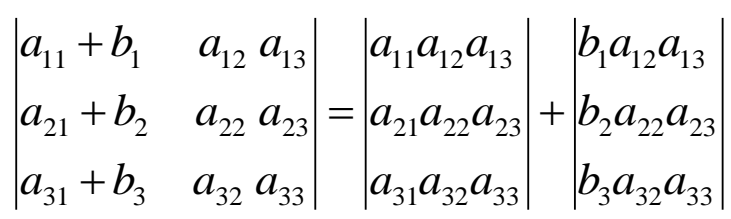

8. If the elements of one column (row) of the determinant multiply the corresponding elements of the other column (row)by the desired total multiplying, then its size will not change, i.e.:

$$
\left|\begin{array}{l}
a_{11} a_{12} a_{13} \\
a_{21} a_{22} a_{23} \\
a_{31} a_{32} a_{33}
\end{array}\right|=\left|\begin{array}{lll}
\left(a_{11}+\lambda a_{12}\right) & a_{12} & a_{13} \\
\left(a_{21}+\lambda a_{22}\right) & a_{22} & a_{23} \\
\left(a_{31}+\lambda a_{32}\right) & a_{32} & a_{33}
\end{array}\right|
$$

Key issues: 1) Direct calculation of the determinant; 2) calculation of the determinant using its properties.

Methods of activity for solving basic tables:

1) Method of activity for calculating the second order determinant:

1. Distinguish the main diagonal, multiplying the elements.

2. Auxiliary diagonal separation, multiplication of elements.

3. Calculate the difference between the first and second multiples.

\section{Writing the answer}

2) Method of activity for direct calculation of the third order determinant:

1. Spread the third-order determinant over the elements of a row or column;

2. Calculation of the second order of determinants, the sum of which is in the formed spread.

3) Method of activity for calculating the third order determinant by a triangular method:

3) Method of activity for calculating the third order determinant by a triangular method: 
1. Divide the elements of the main diagonal and multiply the elements, as well as add the elements of the polygon on the main diagonal by multiplying the elements.

2. Divide the auxiliary diagonal elements and multiply the elements, as well as multiply the elements in a triangular way according to the auxiliary diagonaltirib addition.

3. Calculation of the difference between the generated sums.

\section{Writing the answer}

4) Method of activity for calculating the third order determinant by the method of sarrius (diagonals:

1. Moving two row (column) elements in parallel,

2. Add multipliers and multipliers to the main diagonal and parallel diagonal elements to it;

3. Auxiliary diagonal and to it the addition of multipliers and multipliers of parallel diagonal elements;

4. 2-subtraction of the sum formed in the puncture and 3-subtraction of the sum formed in the puncture.

5. Writing the answer.

5) Method of activity for calculating the n-order determinant:

1. Determination of the Determinant order;

2. Spread on elements of a row or column;

3. Calculation of algebraic fillers (using the calculation, if necessary, reduce the order of the determinant);

4. Calculate the sum and write the answer.

The above-mentioned topic thesaurus will help to describe what concepts and characteristics the student should know, what are the main issues that he / she will be able to solve, the methods of activity for solving these main issues.
It is established that the formation of methods of mental activity in psychology is not a one-time action; this is a process that sometimes takes a very long time. In this process, the researchers divide its individual stages (steps) in different ways. However, it can be noted that the formation of the methods of generalized educational and cognitive activity in students, especially the methods of generalized activity on solving the main issues on the topic, is carried out by going through the following stages:

1) the stage of preparation of students for the mastering of the method, this includes direct preparation for the mastering of the content of the method of activity, generalized by the actualization of motivation and the actualization of the necessary knowledge;

2) the stage of acquaintance with the method, which includes: disclosure of the content (separation of actions for solving specific issues), analysis and comparison of the selected private method, the creation of a generalized method of activity (separation of the general content of private methods);

3) the stage of mastering the method of generalized activity, which implies its application in solving standard issues;

4) the stage of transformation of the mastered method into a new situation, i.e. the transformation of the generalized method in solving problems that have been transformed.

The formation of generalized methods of activity on solving the main issues in students should ensure the gradual passage of the above stages. For this purpose, it is desirable to use cycles of issues corresponding to the stages of formation [7; 8; 9]. In this case, each cycle can be presented in the form of blocks of four interrelated issues:

1) assistive issues serve to up-date the knowledge necessary to address the type of issues to be addressed, as well as to formulate 
motivation to study the generalized ways of solving them;

2) basic issues, the main issues that are intended to determine the composition of the generalized method of activity for solving each type of mathematical problem;

3) questions of exercise, the application of a generalized method of solving certain issues of the standard type and the issues that ensure its assimilation;

4) development issues, transfer of non-standard mathematical issues, a generalized method of solving practical (professional) issues, issues aimed at changing its composition.

In the collections of issues from higher mathematics [for example, 10] 2-,3-, partly 4block issues are common. Here we give examples of auxiliary issues on the above topic.

\section{Auxiliary matters}

1. $\left|\begin{array}{rr}1 & -2 \\ 2 & 4\end{array}\right|$ determine the order of the determinant a); b) write the column elements; c) write the line elements; d) tell the main diagonal Elements; d) tell the auxiliary diagonal elements;

e) calculate the determinant.

$\left|\begin{array}{lr}1 & -2 \\ -1 & 2\end{array}\right|$ determinants.

2. Compare the values of $\left|\begin{array}{ll}1 & -2 \\ 1 & -2\end{array}\right|$ and

3. $\left|\begin{array}{ccc}1 & -2 & 5 \\ 2 & 4 & 0 \\ 1 & 5 & -1\end{array}\right|$ determine the order of the determinant a); b) write the column elements; C) write the line elements; d) tell the main diagonal Elements; D) tell the auxiliary diagonal elements; e) write the minors on the first column; j) write the algebraic fillers on the first column; z) calculate the determinant.

4. Prove $\left|\begin{array}{ccc}1 & -2 & 5 \\ 2 & -4 & 10 \\ 1 & 5 & -1\end{array}\right|$

5. Which of these determinants is equal to

$$
\begin{aligned}
& \text { a) }\left|\begin{array}{ccc}
1 & -2 & 5 \\
1 & -4 & 10 \\
1 & 5 & -1
\end{array}\right| \text {; b) }\left|\begin{array}{ccc}
1 & -2 & 5 \\
1 & -2 & 10 \\
1 & -2 & -1
\end{array}\right| \text {; c) } \\
& \begin{array}{rrr}
1 & -2 & 5 \\
0 & 0 & 0 \\
1 & 5 & -1
\end{array} \mid ; \\
& \text { d) }\left|\begin{array}{ccc}
1 & -2 & 1 \\
1 & -4 & 1 \\
-1 & 5 & -1
\end{array}\right| ; \text { э) }\left|\begin{array}{ccc}
1 & -2 & 5 \\
2 & -4 & 10 \\
1 & 5 & -1
\end{array}\right| \text {. Prove }
\end{aligned}
$$

your answers.

Most of these issues can be done orally. During the implementation of these issues, the student will be up-to-date knowledge acquired in the lecture, read independently from the educational literature; the knowledge by the students will be mastered in the process of carrying out purposeful activities on the content of a concrete subject. So the system of issues serves to implement an active approach to education. It should also be noted that in the process of studying the next subjects of higher mathematics and related (physics, general-vocational, professional) subjects, the competence should be constantly improved. For example, in the process of studying such educational sciences as matrices of higher mathematics, the system of linear equations, the study of subjects related to vectors, physics, the theoretical basis of electro-technics, the formation of competences on the above topic, the student's determinant-related competency is improved.

\section{Conclusion}

1. It was based on the fact that in the process of teaching higher mathematics to future engineers, it is possible to improve on the basis of a fast-paced approach to the implementation of a competency approach.

2. The composition of the mathematical competence of the future engineer on the subject was determined: a) to know the basic concepts and principles of the subject;

b) to know the properties of the basic concepts of the 
CURRENT RESEARCH JOURNAL OF PEDAGOGICS 2(7): 26-33, July 2021

DOI: https://doi.org/10.37547/pedagogics-crjp-02-07-07

ISSN 2767-3278

(C)2021 Master Journals

\section{Crossref do) 81 Google}

Accepted 26 thJuly, 2021 \& Published 31 th July, 2021

subject and the laws that characterize the relationship between the previously studied concepts;

c) to know and apply the methods of action to solve the main issues related to the subject matter;

d) to tour, move the methods of activity to solve the main issues related to the topic in order to solve new issues;

e) to apply the above-mentioned competences in the study of related and professional Sciences.

3. On the topic, the method of formation of the thesaurus and its significance were revealed.

4. It was based on the fact that the cycle of issues consisting of four blocks can be used in the formation of generalized methods of activity on solving the main issues in students.

5. It was noted the need to improve the mathematical competences formed on the subject in the course of further training in the related and general professional disciplines.

\section{REFERENCES}

1. Shershneva V.A. (2011) Formation of mathematical competence of students of an engineering university based on a polyparadigm approach. Abstract of the dissertation for the degree of Doctor of Pedagogical Sciences. Krasnoyarsk - p. 45. (Шершнева B.A. Формирование математической компетентности студентов инженерного вуза на основе полипарадигмального подхода. Автореферат диссертации на соискание ученой степени доктора педагогических наук. Красноярск - 2011. 45 c.)

2. Jafyarov A. J. (2011) Competence approach to the study of the school course of algebra. Pedagogical education and science. No 8. - pp. 64-68. (Жафяров А. Ж. Компетентностный подход к изучению школьного курса алгебры // Педа-гогическое образование и наука. - 2011. - № 8. - С. 64-68.)

3. Jafyarov A. J. (2017) Implementation of the technology of implementation of the competence-based approach in the school course of mathematics. Novosibirsk State Pedagogical University Bulletin. Volume 7. No 2. - pp. 71-84. (Жафяров А. Ж. Реализация технологии внедрения компетентностного подхода в школьном курсе математики// Вестник Новосибирского государственного педагогического университета. - 2017.- том 7. №2. - C. 71-84.)

4. Cojokar O.P. (2009) Thematic thesaurus as a means of developing conceptual thinking in the process of preparing future teachers. Bulletin of the Surgut Pedagogical University. No. 2. - pp. 95-99. (Кожокарь О.П. Тематический тезаурус как средство развития понятийнего мышления в процессе подготовки будущих учителей. //Вестник Сургутского педагогического университета. 2009. №2. С. 95-99.)

5. A. A. Miroshnichenko, I. L. Miroshnichenko Thesaurus as a model of the assigned educational information. International Research Journal. No 12 (54). Part 4. December. DOI: 10.18454 / IRJ.2016.54.236. (Мирошниченко А.А., Мирошниченко И.Л. Тезаурус как модель задаваемой учебной информации// Международный научно-исследовательский журнал. № 12 (54). Часть 4 .Декабрь. DOI: 10.18454/IRJ.2016.54.236.)

6. Turgunbaev R.M. (2021) Formation of the educational thesaurus of mathematical analysis and its importance. The teacher also provides continuous education. №1. - pp. 127-132. (Тургунбаев Р.M. Математик анализ фанининг ўқув тезаурусини шакллантириш ва унинг ахамияти // Муғаллим хәм үзликсиз билимлендириў. 2021. №1. 127-132б.)

7. Episheva O.B., Krupich V.I. (1990) Teaching students to learn mathematics: Formation of methods of educational activities. - Moscow: 
CURRENT RESEARCH JOURNAL OF PEDAGOGICS 2(7): 26-33, July 2021

DOI: https://doi.org/10.37547/pedagogics-crjp-02-07-07

ISSN 2767-3278

(C)2021 Master Journals

Crossref doi 8 Google

Accepted 26thJuly, 2021 \& Published 31 th July, 2021

Education. - p. 128. (Епишева О.Б., Крупич В.И.

Учить школьников учиться математике:

Формирование приемов учебной

деятельности. - М.: Просвещение. - 1990. 128 c.)

8. Reader on the method of mathematics: Learning through problems. Compiled by M.I. Zaikin, S.V. Aryutkina. - Arzamas: Arkhangelsk State Pedagogical Institute. 2005 - p. 300; (Хрестоматия по методике математики: Обучение через задачи / Сост. М.И. Зайкин, С.В. Арюткина. - Арзамас: АГПИ. - 2005. - 300 C.;)

9. Aryutkina S.V. (2012) Formation of generalized techniques of priority types of mathematical activity among students of specialized classes and schools. Bulletin Orenburg State University. No 2 (138). - pp. 10-15. (Арюткина С.В. Формирование обобщенных приемов приоритетных видов математической деятельности у учащихся профильных классов и школ// Вестник ОГУ №2 (138), 2012. С.10-15.)

10. Danko P.E. (2007) A set of examples and problems in higher mathematics. Textbook. Part 1. - Tashkent: "Uzbekistan". - p. 248. (Данко П.Е. “Олий математикадан мисол ва масалалар тўплами”. Дарслик. 1-қисм. Т.:“Ўзбекистон”, 2007. - 248 б.) 